\title{
Malignant granular cell myoblastoma
}

\author{
D. H. MACKENZIE
}

From the Department of Morbid Anatomy, Westminster Hospital, London

SYNOPSIS A case of granular cell myoblastoma which metastasized with fatal results is described. The literature relating to similar cases is reviewed and a total of 13 acceptable cases is listed.

The precise nature of the lesions which have been called granular cell myoblastomas for $\mathbf{4 0}$ years is still uncertain. There is no doubt, however, that innocence of behaviour is a very constant feature and the great rarity of metastasizing lesions seems to justify the present case report. Those who are interested in discussions on histogenesis are referred to the excellent paper of Fisher and Wechsler (1962). These writers concluded that the lesions were granular cell 'Schwannomas', not necessarily neoplastic.

It is unfortunate that Abrikossoff (1926) in his original description included in his fourth group tumours which were either rhabdomyosarcomas or sarcomas of uncertain nature whose histology differed widely from the typical granular cell pattern. Since then there has been a recurring tendency to include under the title 'myoblastoma' a number of tumours of differing histogenesis which happen to include occasional cells with a granular appearance. For example, the cases reported by Hartz (1944), Ackerman and Phelps (1946), Meredith, Kay, and Bosher (1958) and others, appear to the writer to be alveolar soft part sarcomas and there seems little justification for labelling these 'granular cell myoblastomas with an organoid pattern'. Thus, any case which is claimed to represent a true malignant granular cell myoblastoma needs very careful examination (Gamboa, 1955).

The following case appears to have all the necessary qualifications for inclusion.

\section{CASE REPORT}

The patient, a woman of 82 , presented with a mobile, slightly tender lump about $6 \mathrm{~cm}$. in diameter in the left lumbar region. No other abnormalities were discovered at that time. The lump was excised and showed the typical histology of a granular cell myoblastoma with no features of malignancy. She remained well for two years and was then referred to Westminster Hospital with a local recurrence $7 \mathrm{~cm}$. in diameter; a mass $6 \mathrm{~cm}$. in diameter in

Received for publication 16 March 1967. the left axilla and a mass $4 \mathrm{~cm}$. in diameter in the left groin. All these lesions were treated by supervoltage radiotherapy to a total of 5,700 r. with partial regression. Six months later the three tumours began to increase in size and further lesions appeared in the left breast and right groin. Her health steadily deteriorated and she died after a total illness of three years and three months.

NECROPSY FINDINGS The body was that of a wasted elderly woman. There were visible tumour masses in both groins and in the left lumbar region. A left bloodstained pleural effusion was present and there were multiple metastases in both lungs, one of which was invading the pericardium. The peritoneal cavity was free of growth. There was a large local recurrence at the primary site involving surrounding muscles, and invaded lymph nodes were found in the left axilla and both inguinal regions. There was also a tumour deposit in the left breast.

HISTOLOGY All the main tumour deposits were examined. Sections were stained with haematoxylin and eosin; P.A.S. (with and without diastase treatment); P.T.A.H.; Best's carmine; Masson's trichrome and Gomori's method for reticulin. Herxheimer's stain for fat was done on frozen sections. The histology was remarkably constant and every section showed appearances typical of granular cell myoblastoma. Mitotic figures were not observed. In some sections tumour cells were seen in lymphatics and invasion of pulmonary veins was also noted. There were no appearances suggestive of any other type of tumour.

The staining reactions of these tumours are known to be variable. In this case the cytoplasmic granules were P.A.S. positive with and without diastase treatment. With Masson's trichrome they stained a reddish brown colour. Fat stains were negative. The histological appearances are shown in Figures 1-4.

\section{DISCUSSION}

Gamboa (1955) stated that there were 10 acceptable cases of malignant granular cell myoblastomas and added one of his own. He rejected 21 cases on the grounds that, judging from descriptions and photomicrographs, they were or could have been rhabdomyosarcomas or alveolar soft part sarcomas. The 


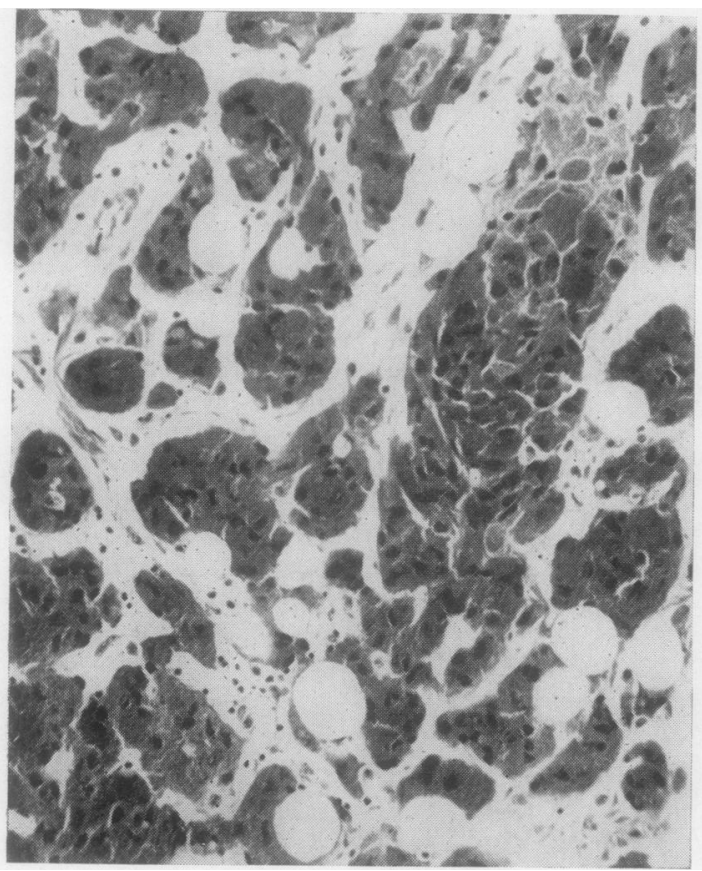

FIG. 1. The primary tumour showing clumps of granular cells. H. and E. $\times 100$.

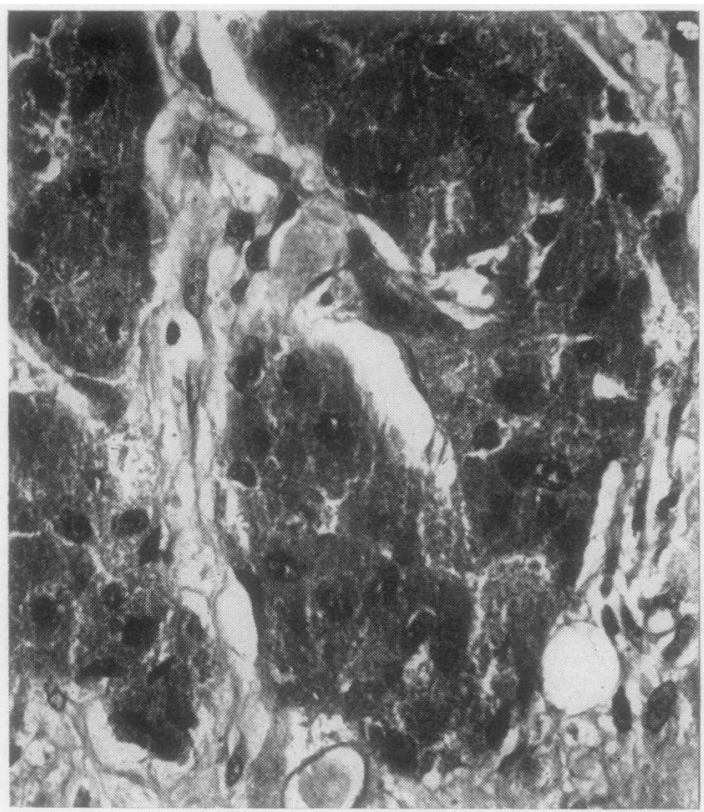

FIG. 2. Recurrence at primary site showing P.A.S.positive granules. P.A.S. $\times 125$.

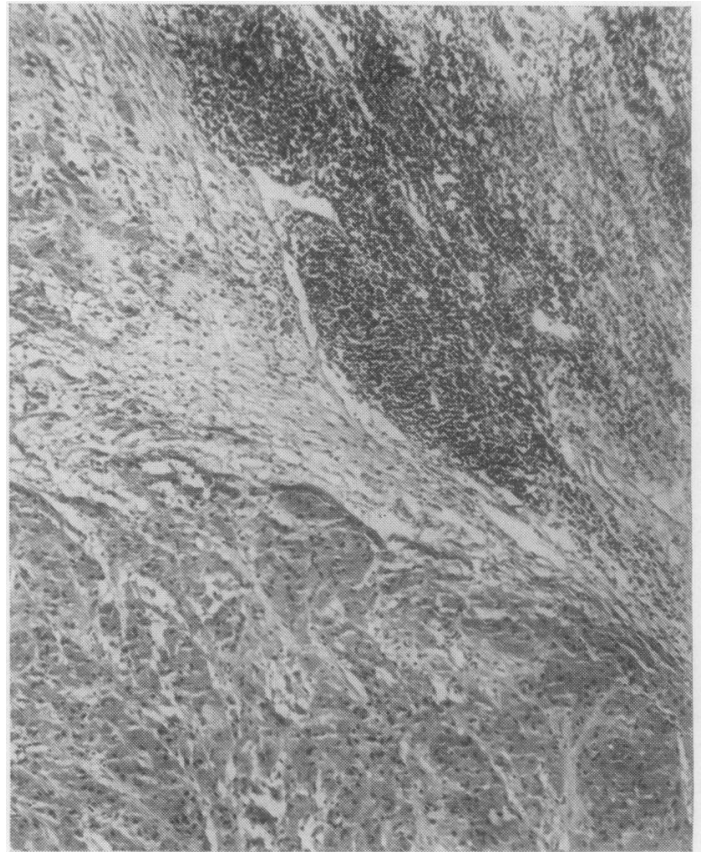

FIG. 3 Metastasis in inguinal node. $H$. and $E$. $\times 50$.

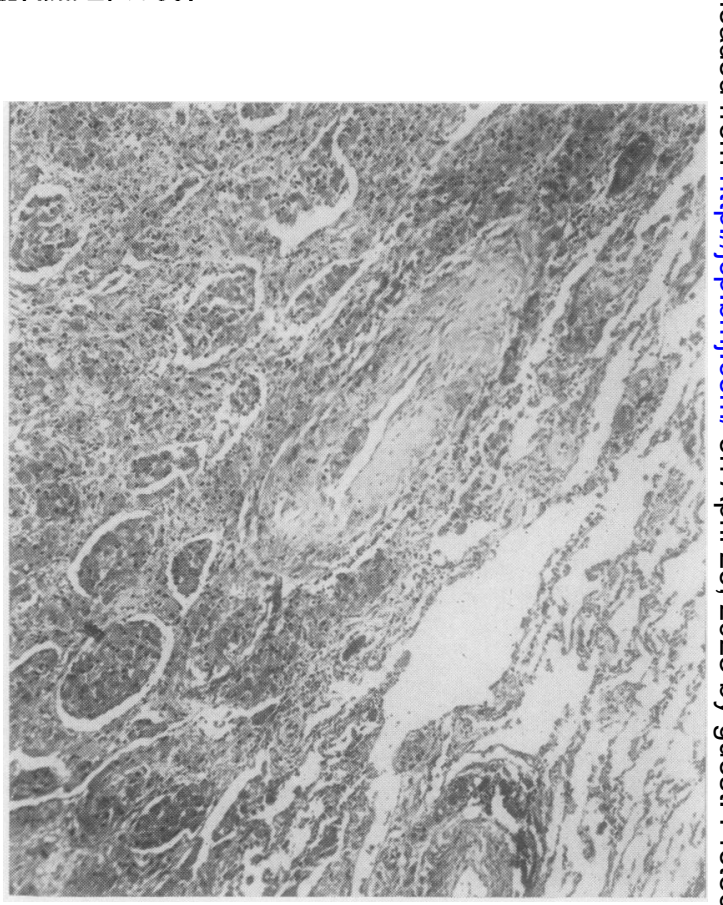

FIG. 4. Pulmonary metastasis showing tumour cells in and around a pulmonarv vein. $H$. and $E$. $\times 38$. 
writer has re-examined these reports and agrees with his findings with two exceptions. The case described by Schwidde, Meyers, and Sweeney (1951) looks like an alveolar soft part sarcoma and is excluded. Case 8 is substituted for case 9 in the cases of Howe and Warren (1944) excluded by Gamboa. There was no suggestion of malignancy in case 9. Case 2 of Crawford and de Bakey (1953) is a follow up of that of Powell (1946).

Since 1955 we have been able to find seven further reports of malignant granular cell myoblastomas. Svejda and Horn (1958) described a case of a 48-yearold female who had a small tumour removed from the right groin. Three years later she died with disease in the intestines, peritoneum, lymph nodes, heart, and lungs. This case is acceptable although the authors considered that this was not a true tumour but a generalized mesenchymal degeneration attacking particularly muscle cells, fibrocytes, and histiocytes. In the same year Meredith et al. described a metastasiz- ing granular cell tumour of organoid type but, in the writer's view, this was an alveolar soft part sarcoma. Hunter and Dewar (1960) described a tumour of the colon in a 75-year-old woman which in some areas was histologically malignant. However, there was no record of recurrence or distant spread. In 1962 Caby, Duperrat, and Ecochard described a case of a 40-yearold woman with a tumour of the right groin which metastasized. The quality of the photomicrographs make this case difficult to assess and it has been excluded. The case of Krieg (1962) also appears doubtful. The photomicrographs are unconvincing and his ribbon-like' and 'elongate' cells suggest a possible rhabdomyoblastic origin. Kirschner (1962) described a myoblastoma of the breast which he regarded as malignant on histological grounds. There was no evidence, however, of metastatic spread. We have been unable to study the case reported by Pulsoni (1963). Since that time the writer has been unable to find any other reports of metastasizing granular cell

TABLE I

CASES WITH METASTASES

\begin{tabular}{|c|c|c|c|c|c|c|c|c|}
\hline $\begin{array}{l}\text { Case } \\
\text { No. }\end{array}$ & $\begin{array}{l}\text { Year } \\
\text { Author } \\
\text { Case No. }\end{array}$ & Age & $\operatorname{Sex}$ & $\begin{array}{l}\text { Site of } \\
\text { Primary }\end{array}$ & $\begin{array}{l}\text { Signs and } \\
\text { Symptoms }\end{array}$ & Therapy & Subsequent History & $\begin{array}{l}\text { Duration } \\
\text { of } \\
\text { Illness } \\
\text { (mth.) }\end{array}$ \\
\hline 1 & $\begin{array}{l}1945 \\
\text { Ravich et al. }\end{array}$ & 31 & Male & $\begin{array}{l}\text { Urinary } \\
\text { bladder }\end{array}$ & $\begin{array}{l}\text { Haematuria } \\
\text { and frequency }\end{array}$ & $\begin{array}{l}\text { Excision and } \\
\text { radiotherapy }\end{array}$ & $\begin{array}{l}\text { Died } 17 \text { months after excision } \\
\text { with metastases to nodes, bones, } \\
\text { lung, pericardium, peritoneum, } \\
\text { liver, spleen, prostate }\end{array}$ & 17 \\
\hline 2 & $\begin{array}{l}1953 \\
\text { Crawford and De Bakey } \\
\text { Case } 1\end{array}$ & 50 & Female & Breast & $\begin{array}{l}\text { Lump in } \\
\text { breast }\end{array}$ & Supportive & $\begin{array}{l}\text { Metastases to left lung, liver, } \\
\text { and coeliac nodes; died after } \\
12 \text { months }\end{array}$ & 12 \\
\hline 3 & $\begin{array}{l}1953 \\
\text { Crawford and De Bakey } \\
\text { (Powell, 1946) }\end{array}$ & 31 & Female & $\begin{array}{l}\text { Subcutaneous } \\
\text { nodules over } \\
\text { trunk and } \\
\text { extremities }\end{array}$ & $\begin{array}{l}\text { Skin } \\
\text { nodules }\end{array}$ & $\begin{array}{l}\text { Excision and } \\
\text { radiotherapy }\end{array}$ & $\begin{array}{l}\text { Metastases to uterus and } \\
\text { ovaries after } 14 \text { years; to } \\
\text { tongue, lip, vulva, oesophagus } \\
\text { and neck after } 20 \text { years }\end{array}$ & 240 \\
\hline 4 & $\begin{array}{l}1955 \\
\text { Gamboa }\end{array}$ & 30 & Female & Thigh & Painful lump & $\begin{array}{l}\text { Excision and } \\
\text { radiotherapy }\end{array}$ & $\begin{array}{l}\text { Metastases to inguinal lymph } \\
\text { nodes and left lung after } 3 \text { years }\end{array}$ & 60 \\
\hline 5 & $\begin{array}{l}1948 \\
\text { Dunnington } \\
\text { Case } 2\end{array}$ & 40 & Male & Eyelid & $\begin{array}{l}\text { Swelling of } \\
\text { eyelid }\end{array}$ & Excision & $\begin{array}{l}\text { Generalized metastases after } \\
2 \text { years }\end{array}$ & 24 \\
\hline 6 & $\begin{array}{l}1949 \\
\text { Ceelen }\end{array}$ & 45 & Female & Arm & $\begin{array}{l}\text { Multiple } \\
\text { tumours of } \\
\text { left arm }\end{array}$ & Excision & $\begin{array}{l}\text { Metastases to axillary nodes, } \\
\text { breast, and lungs after } 1 \text { year }\end{array}$ & 54 \\
\hline 7 & $\begin{array}{l}1952 \\
\text { Ross et al. } \\
\text { Case } 1\end{array}$ & 60 & Male & $\begin{array}{l}\text { Lumbosacral } \\
\text { area }\end{array}$ & $\begin{array}{l}\text { Swelling in } \\
\text { lumbosacral } \\
\text { area }\end{array}$ & Excision & $\begin{array}{l}\text { Metastases to inguinal nodes } \\
\text { and lungs after } 3 \text { years }\end{array}$ & 36 \\
\hline 8 & $\begin{array}{l}1952 \\
\text { Ross et al. } \\
\text { Case } 2\end{array}$ & 58 & Female & $\begin{array}{l}\text { Skin of left } \\
\text { ankle }\end{array}$ & $\begin{array}{l}\text { Swelling over } \\
\text { left ankle }\end{array}$ & $\begin{array}{l}\text { Excision and } \\
\text { radiotherapy }\end{array}$ & $\begin{array}{l}\text { Metastases to inguinal nodes; } \\
\text { died after } 8 \text { years }\end{array}$ & 96 \\
\hline 9 & $\begin{array}{l}1958 \\
\text { Svejda and Horn }\end{array}$ & 48 & Female & Right groin & $\begin{array}{l}\text { Lump in } \\
\text { groin }\end{array}$ & $\begin{array}{l}\text { Excision and } \\
\text { radiotherapy }\end{array}$ & $\begin{array}{l}\text { Metastases to intestines, liver, } \\
\text { lymph nodes, peritoneum, } \\
\text { pleura, myocardium, lungs, } \\
\text { abdominal wall }\end{array}$ & 42 \\
\hline 10 & $\begin{array}{l}1967 \\
\text { Mackenzie }\end{array}$ & 82 & Female & Left loin & Lump in loin & $\begin{array}{l}\text { Excision and } \\
\text { radiotherapy }\end{array}$ & $\begin{array}{l}\text { Metastases to lungs, lymph } \\
\text { nodes, and breast }\end{array}$ & 39 \\
\hline
\end{tabular}


TABLE II

\begin{tabular}{|c|c|c|c|c|c|c|c|c|}
\hline \multirow[b]{2}{*}{$\begin{array}{l}\text { Case } \\
\text { No. }\end{array}$} & \multirow[b]{2}{*}{$\begin{array}{l}\text { Year } \\
\text { Author } \\
\text { Case No. }\end{array}$} & \multirow[b]{2}{*}{ Age } & \multirow[b]{2}{*}{ Sex } & \multicolumn{3}{|c|}{ CASES WITH SUCCESSFUL RESULT } & \multirow[b]{2}{*}{ Subsequent History } & \multirow[b]{2}{*}{$\begin{array}{l}\text { Duration of } \\
\text { Illness }\end{array}$} \\
\hline & & & & $\begin{array}{l}\text { Site of } \\
\text { Primary }\end{array}$ & $\begin{array}{l}\text { Signs and } \\
\text { Symptoms }\end{array}$ & Therapy & & \\
\hline 11 & $\begin{array}{l}1952 \\
\text { Ross et al. } \\
\text { Case } 3\end{array}$ & 33 & Female & Left thigh & $\begin{array}{l}\text { Asympto- } \\
\text { matic lump }\end{array}$ & Excision & $\begin{array}{l}\text { Recurred } 5 \text { months after } \\
\text { initial excision; no further } \\
\text { trouble after second excision }\end{array}$ & $\begin{array}{l}\text { Alive and well } \\
170 \text { months }\end{array}$ \\
\hline 12 & $\begin{array}{l}1960 \\
\text { Hunter and Dewar }\end{array}$ & 75 & Female & Colon & $\begin{array}{l}\text { Abdominal } \\
\text { pain }\end{array}$ & Excision & $\begin{array}{l}\text { No recurrence or metastases } \\
\text { after } 15 \text { months }\end{array}$ & $\begin{array}{l}\text { No recent } \\
\text { follow-up } \\
\text { available }\end{array}$ \\
\hline 13 & $\begin{array}{l}1962 \\
\text { Krischner }\end{array}$ & 67 & Female & Breast & $\begin{array}{l}\text { Lump in } \\
\text { breast }\end{array}$ & Excision & No recurrence or metastases & $\begin{array}{l}\text { No recent } \\
\text { follow-up } \\
\text { available }\end{array}$ \\
\hline
\end{tabular}

myoblastomas. It is worth mentioning, however, that there have been reports of multiple tumours of this type with no sign of malignancy (Baraf and Bender, 1964; Ullman and Dacro, 1965).

In a review like this dependence upon written descriptions and photomicrographs can mean that some cases are included or excluded wrongly. There is the added difficulty here that acceptance or rejection may depend on the assessor's view of histogenesis. For example, if these tumours are regarded as malignant schwannomas then only schwannomatous tissue is permissible in addition to the granular cells. On the other hand, if the granularity is regarded as a degenerative or metabolic change which may affect a variety of mesenchymalcells, as suggested by Svejda and Horn (1958) and Sobel and Churg (1964), then the number of acceptable cases must increase. In the present uncertainty only those cases where the typical granular cells predominated in the primary tumour and in the metastases and where there was no evidence of any other type of malignant neoplasm, have been accepted.

These cases are shown in Tables I and II. Table I includes those where the tumour gave rise to definite metastases. Table II includes three cases where the tumour appeared histologically malignant but where, apart from one recurrence, excision resulted in apparent cure. The total number of cases is 13 . The writer believes that these are malignant neoplasms. However, the possibility that the granular cell appearances may result from some degenerative or metabolic change is not excluded. In malignant cases such a change would be associated with true neoplasia.

I wish to thank Mr.A.Cruickshank and Mr. T. M. Prossor for permission to publish this case and Dr. M. E. A. Powell for the first histology report. I am indebted to Dr. F. W. Foote for follow up information on case 11, and to the Department of Medical Photography, Westminster Medical School.

\section{REFERENCES}

Abrikossoff, A. (1926). Virchows Arch. path. Anat., $260,215$.

Ackerman, L. V., and Phelps, C. R. (1946). Surgery, 20, 511.

Baraf, C. S., and Bender, B. (1964). Arch. Derm. (Chic.), 89, 243.

Caby, F., Duperrat, B., and Ecochard, J. C. (1962). Sem. Hôp. Paris, 38, 1930.

Ceelen, W. (1949). Zbl. allg. Path. path. Anat., 85, 289.

Crawford, E. S., and de Bakey, M. E. (1953). Cancer (Philad.), 6, 786.

Dunnington, J. H. (1948). Arch. Ophthal. (Chic.), 40, 14.

Fisher, E. R., and Wechsler, H. (1962). Cancer (Philad.), 15, 936.

Foote, F. W. (1967). Personal communication.

Gamboa, L. G. (1955). Arch. Path. (Chic.), 60, 663

Hartz, P. H. (1944). Amer. J. clin. Path., 14, 582.

Howe, C. W., and Warren, S. (1944), Surgery, 16, 319.

Hunter, D. T. Jr., and Dewar, J. P. (1960). Amer. Surg., 26, 554.

Kirschner, H. (1962). Bruns' Beitr. klin. Chir., 204, 87.

Krieg, A. F. (1962). Arch. Path., 74, 251.

Meredith, J. M., Kay, S., and Bosher, L. H., Jr. (1958). J. thorac. Surg., $35,80$.

Powell, E. B. (1946). Arch. Path., 42, 517.

Pulsoni, P., and Zell, G. P. (1963). Gazz. int. Med. Chir., 68, 3022.

Ravich, A., Stout, A. P., and Ravich, R. A. (1945). Ann. Surg., 121, 361 .

Ross, R. C., Miller, I. R., and Foote, F. W., Jr. (1952). Cancer (Philad.), 5, 112.

Schwidde, J. T., Meyers, R., and Sweeney, D. B. (1951). J. Neuropath. exp. Neurol., 10, 30.

Sobel H. J., and Churg, J. (1964). Arch. Path., 77, 132.

Svejda, J., and Horn, V. (1958). J. Path. Bact., 76, 343.

Ullmann, A. S., and Dacso, M. R. (1965). Canad. med. Ass. J., 92, 531. 